\title{
The Role of Individual Characteristics, CSR Information, Financial and Non-Financial Compensation to Job Seekers Interests in A Company
}

\author{
PUTRI PARAMITA AGRITANSIA* \\ RESA MASELA KHAIRUNNISA \\ THAREQ AKBAR ADIGUNA \\ Universitas Gadjah Mada
}

\begin{abstract}
Human resources are the key to achieving and maintaining corporate goal(s). Obtaining high-quality human resources is a challenging task for every corporation. Therefore, corporations compete in providing attractive compensation packages to both its current and prospective employees. The objective of this study is three folds. Firstly, this study seeks to explore the effect of information on compensation and corporate social responsibility (CSR) disclosures toward fresh-graduate job seekers interests of a company. Next, the objective of this study is to examine the interactional effects between the prior mentioned independent variables. Lastly, this study is conducted to examine the role of moral reasoning as a moderating variable in the relationship between those mentioned above independent and dependent variables. In examining the relationship, this study uses the moderated regression analysis. This study is an experimental study that adopts $2 \times 2$ designs amongst subjects. Information on compensation and CSR disclosures are manipulated in this study. The total of thirty-seven people consisted of the final semester undergraduate students and recent bachelor degree graduates participated in this study. In analyzing the collected data, this study uses ANOVA. This study finds that only corporate CSR disclosures affect fresh-graduate job seekers work intention in a corporation.
\end{abstract}

Keywords: CSR, moral reasoning, information on compensation, Social Identity Theory

Intisasri: Sumber daya manusia adalah kunci untuk mencapai dan mempertahankan tujuan perusahaan (s). Memperoleh sumber daya manusia berkualitas tinggi adalah tugas yang menantang bagi setiap perusahaan. Oleh karena itu, perusahaan bersaing dalam menyediakan paket kompensasi yang menarik bagi karyawan saat ini dan calon karyawannya. Tujuan dari penelitian ini adalah tiga kali lipat. Pertama, penelitian ini berusaha untuk mengeksplorasi efek informasi tentang kompensasi dan tanggung jawab sosial perusahaan (CSR) pengungkapan terhadap minat pencari kerja fresh-graduate perusahaan. Selanjutnya, tujuan dari penelitian ini adalah untuk menguji efek interaksional antara variabel independen yang disebutkan sebelumnya. Terakhir, penelitian ini dilakukan untuk menguji peran penalaran moral sebagai variabel moderasi dalam hubungan antara yang disebutkan di atas variabel independen dan dependen. Dalam memeriksa hubungan, penelitian ini menggunakan analisis regresi

\footnotetext{
*Corresponding author: pagritansia@ugm.ac.id
} 
moderat. Penelitian ini merupakan penelitian eksperimental yang mengadopsi desain $2 \times 2$ di antara subjek. Informasi tentang kompensasi dan pengungkapan CSR dimanipulasi dalam penelitian ini. Sebanyak tiga puluh tujuh orang terdiri dari mahasiswa sarjana akhir semester dan lulusan gelar sarjana baru berpartisipasi dalam penelitian ini. Dalam menganalisis data yang dikumpulkan, penelitian ini menggunakan ANOVA. Studi ini menemukan bahwa hanya pengungkapan CSR perusahaan yang mempengaruhi niat kerja pencari kerja lulusan baru dalam suatu perusahaan.

Kata kunci: CSR, Penalaran Moral, Informasi Tentang Kompensasi, Teori Identitas Sosial

\section{Introduction}

Quality of labor is an essential factor in a Human Resources (HR) aspect that contributes to the achievement of corporate objectives (Pfeffer, 1994; Snell et al., 1996). One of the essential elements in HR is recruitment (Taylor \& Collins, 2000) because recruitment is the stage where the company can recruit employees with the best qualities and talents that can synergize and contribute to the achievement of corporate goals. Therefore, it is crucial for the company to attract qualified job seekers to make the company have high-quality human resources.

Meanwhile, the quality of labor in Indonesia is relatively low. This is demonstrated by data from the Ministry of Manpower and Transmigration cited in an article on the Ministry of Industry of the Republic of Indonesia which states that as of August 2012, out of 118.05 million registered workers, there are only 8.17 million people who hold a degree or degrees. Thus, companies in Indonesia must compete for a limited number of qualified job seekers. It is because the higher the company's ability to attract qualified job seekers, the higher the chances of the company to recruit the best quality human resources. Therefore, companies must know factors which can attract qualified job seekers.

Two of the factors in the attractiveness of in the company that influence job seekers include compensation offered by the company (Arthur, 2001) and the company's reputation (Belt and Paolillo, 1982; Gatewood et al., 1993). After all, everyone is interested in meeting their economic needs. Arthur (2001) stated that a person tends to choose to work in a company that can compensate according to the level of education 
and work experience she/he has. Thus, the higher the quality of a job seeker, the higher the compensation package that she/he expects to receive.

Meanwhile, the reputation of the company is closely related to CSR activities performed (Fombrun and Shanley, 1990). The role of reputation associated with CSR in influencing the attractiveness of job seekers in the company can be explained by social identity and signaling theory. According to the theory of social identity, a person's image is influenced by his involvement in various social groups (Tajfel \& Turner, 1979). Based on the theory, a person tends to choose to work in a company that has a good reputation for him. He is considered a good person as well. According to the signaling theory, CSR activities give the company a signal about the values and norms of the company, as well as affect perceptions about working conditions in the company, which then impact on the company's ability to attract prospective employees (Greening \& Turban, 2000). Corporate CSR activities are communicated to external parties through CSR disclosure, either through annual reports, online pages, brochures, paid papers, and so on. Disclosure of this CSR-related information forms the company's reputation (Gatewood, Gowan, \& Lautenschlager, 1993). According to the theory of voluntary disclosure, the better the company's social and corporate performance (abbreviated CSP), the company is increasingly compelled to make CSR disclosures more extensively (Clarkson, Li, Richardson, \& Vasvari, 2008). Research conducted by Greening and Turban (2000) found that CSR activity is more interesting than compensation offered by companies for job seekers. The findings support the results of a survey conducted by Students for Responsible Business for 2,100 MBA students. The survey found that more than half of respondents were willing to receive lower salaries from companies that performed good social responsibility (Dolan, 1997).

There have been several studies that found that there is a positive relationship between the company's reputation on CSR activity and the company's ability to attract job seekers (Albinger and Freeman, 2000; Greening and Turban, 2000). However, previous studies have not taken into consideration the individual characteristics that may affect the relationship between variables. This study deepens the previous research by considering the individual characteristics that might affect the relationship such as the 
level of individual moral reasoning, especially in fresh-graduates job seekers. The level of moral reasoning is predicted to affect the perception of job seekers about CSR activities of the company. This is because one's perception of the company's ethical actions is not the same. A social phenomenon can be interpreted in different ways by two different people (Piaget, 1932). This perceptual difference in ethical conformity is influenced by the moral reasoning of each individual (Kohlberg, 1981).

This study purpose is to determine whether job seekers consider economic and noneconomic factors in determining the company as their place of work later, and which factors are more dominant in influencing their interest in a company. Economic factors are represented by the compensation information the company offers, and CSR disclosures by the company represent the non-economic factors. Also, this study aims to determine whether the level of individual moral reasoning leads to differences in interest between job seekers for the same extent of CSR disclosure.

\section{Theoretical Framework and Hypothesis Development}

\subsection{CSR Disclosure}

All corporate CSR activities are communicated to the public through CSR disclosure responsibilities. The disclosure can be done using various media, such as company annual report, company website, paid papers, brochures, press releases, and television and radio advertisements (Rockness, Bazley, \& Nikolai, 1977).

In an international context, one set of guidelines for companies in disclosing their CSR activities is the G4 Sustainability Reporting issued by Global Reporting Initiatives. In Indonesia, the disclosure of CSR activities of companies is regulated by law No. 40 the year 2007 Article 66. Although there are underlying laws for limited liability companies in Indonesia to conduct and report on their CSR activities, there are no standard criteria. Therefore, the implementation and disclosure of CSR in Indonesia are currently still voluntary. 


\subsection{Social Identity Theory}

This theory explains that self-image is influenced by its involvement in various social groups (Tajfel \& Turner, 1979). Greening and Turban (2000) argue that the selfimage of an employee is influenced by the image and reputation of the company where he works, in which the company's image and reputation are influenced by the company's actions on social and political issues. Greening and Turban (2000) argue that corporate social and corporate performance (CSP) positively affects the attractiveness of firms in the perspectives of job seekers. This is because job seekers have positive information related to the company that will reinforce their self-concept as a part of a company that has good social responsibility.

\subsection{Signaling Theory and Voluntary Disclosure}

The signaling theory explains that while there are no regulations requiring companies to report, companies will keep reporting voluntarily (Wolk, Dodd, \& Rozycki, 2013). However, internal parties have more information than external parties. This is referred to as information asymmetry. The incompleteness information may affect the value of the company in the capital market. Voluntary disclosure is considered a signal that can reduce the uncertainty of information owned by external parties that can increase the value of the company (Wolk, Dodd, \& Rozycki, 2013). In the eyes of job seekers, company disclosure of social and environmental information (CSR disclosure) to the public is voluntarily considered as a signal that gives an idea of the working conditions in the company (Greening \& Turban, 2000). Jobseekers use information about the company's actions regarding social and environmental issues to consider the options of the company that will be where they work.

According to the voluntary disclosure theory, there is a positive relationship between corporate social and environmental performance (CSP) and the level of CSR disclosure done by the company. Companies with better social and environmental performance tend to disclose more extensively to the public than companies with lower social and environmental performance (Clarkson, Li, Richardson, \& Vasvari, 2008). 


\subsection{Moral Reasoning}

Moral reasoning is a process of reasoning from human behavior, organization, or policy that its value is suitable with moral standards (Velasquez, 2012). Lawrence Kohlberg, a psychologist who began research in this field, found that the stages of human moral development can be divided into three levels, where each level has two steps (Velasquez, 2012). At the first level (pre-conventional level), a decision whether a behavior is good, bad, right, or wrong based on the consequences received. A person who has a level of moral development at this stage prioritizes his personal interests to make moral decisions (egocentric). In the second level (conventional level), the decision is based on the values, norms, and laws applicable in the environment. A person whose level of moral development is at this stage will make moral decisions based on society's expectations and the laws prevailing in his environment. At the third level (postconventional level), moral decisions are based on a broader and universal perspective. A person who has a level of moral development at this stage will make moral judgments rationally and critically and can explain the reasons behind the virtue based on moral principles (Velasquez, 2012).

\subsection{Hypothesis Development}

Every human being wants to meet his economic needs. The importance to fulfill the economic needs become one of the factors that influence a person in choosing the company as a place to work. Education and experience levels are the driving factors for higher compensation (Arthur, 2001)

H1. More job seekers interested in working for a company that offers a higher compensation than the average industry rather than a company with the compensation at an average industry.

Several studies have found that a reputation that is shaped by the company's social and environmental performance (CSP) establishes attractiveness for a company. Greening and Turban (2000) found that all CSP components (relationships with 
employees, treatment of women and minorities, environmental concerns, and product quality) are positively related to the attractiveness of prospective employees to a company. In support of the research, Albinger and Freeman (2000) tried to find the effect of CSP on the interest of various job-seeker groups. The study found that higherquality job seekers and more employment options tend to consider more CSPs in choosing a company as a place of employment than those with lower quality job seekers and fewer job options.

According to voluntary disclosure theory, firms with better CSPs tend to disclose their CSR activities more extensively, so the better the company's CSP, the higher the CSR disclosures are made (Clarkson, Li, Richardson, \& Vasvari, 2008). Following the signaling theory, the more information related to CSR disclosed by the company, the more job seekers have a picture of working conditions in the company. The theory of social identity states that job seekers tend to choose companies that have better CSPs because companies with a good CSR reputation will strengthen their self-image. Referring to those three theories, it can be concluded that the better the CSP of a company, the higher (extensive) CSR disclosure of the company (Clarkson, Li, Richardson, \& Vasvari, 2008), therefore the higher the attraction of the company in the eyes of job seekers (Albinger andFreeman, 2000; Greening and Turban, 2000)

H2. Job seekers are more interested in working in companies that have high CSR disclosures than companies with low CSR disclosure.

Some research proves that from both of these factors, companies with better CSR reputation has a greater influence in determining one's interest in a company. Students for Responsible Business surveyed 2,100 MBA students and found that more than half of respondents stated that they did not object to receiving a lower salary from companies with social responsibility (Dolan, 1997). Supporting the results of the study, Greening and Turban (2000) found that there was no significant relationship between compensation and the attractiveness of prospective employees to the company. 
H3. Job seekers are more interested in working in companies that have higher CSR disclosures with compensation as big as industry average rather than in companies that have low levels of CSR disclosure with compensation above the industry average.

One's perception of a company's ethical actions is not the same. Two different people can interpret a social phenomenon in a different way (Piaget, 1932). This is due to differences in the level of moral reasoning possessed by each individual (Kohlberg, 1981). Thus, the interpretation of a company's CSR disclosure will result differently in the level of interest in the firm between job seekers with each other. This is due to differences in the level of moral reasoning possessed by job seekers.

H4. Individual moral reasoning moderates the influence of CSR disclosure on the attractiveness of job seekers in a company.

\section{Research methods}

\subsection{Experimental Procedures and Participants}

This research uses an experimental laboratory method (experimental lab $t$ ). The experimental design used is $2 \times 2$ between subjects. There are two manipulations for two variables (i.e., compensation and CSR disclosure) tested. Manipulation is done by regulating the high and low value of compensation the company offers to employers and broad or narrow disclosure of corporate CSR.

Participants in this research are final graduate students and recently graduated from Bachelor Program of Faculty of Economics and Business UGM with a total of 60 people consisting of Accounting Department (20 persons), Management Department (20 persons), and Economics Department (20 persons). Participants were distributed into four groups proportionally based on majors and gender. Group A is a group that obtains high compensation information and high CSR disclosure. Group B is a group that gets high compensation information and low CSR disclosure. Group C is a group that receives low compensation information and high CSR disclosure. Group D is a group that receives low compensation information and low CSR disclosure. 


\subsection{Research Instruments}

This study used two instruments: 1) an evaluation instrument on the interest of job seekers at the company, and 2) the instrument Defining Issues Test (DIT). The first instrument test the company attractiveness from job seekers point of view adopted from Greening and Turban (2000) research instruments with modifications. This instrument consists of two treatments for two conditions. These conditions include information on compensation and disclosure of CSR. The manipulations for each coefficient are high and low. In this instrument, it is mentioned that the participants had just passed the comprehensive test from the college and are in search of work. Participants will be given exposure to information about a company, then asked to determine their level of interest in the company by providing a score on the four statements given. The interest is represented by a scale of 1-7, with 1: strongly disagree and 7 : strongly agree to the first two statements. In the next two statements, participants were asked to provide a percentage indicating their interest in the company by filling in a score between $0 \%$ $100 \%$.

a. Compensation Information

Manipulation for compensation information is adopted from Greening and Turban (2000) research instruments. In the high-compensation information scenario, it is stated that the company offers a highly competitive compensation package, which is above the industry average, comprehensive facilities and benefits covering dental, eyes and long-term disability insurance, industrystandard pension plans, and the right to buy the company's stock at a special price. In the low compensation information scenario, it is stated that the company offers a compensation package with a salary equal to the industry average, days off allowance, sickness compensation and holiday compensation, as well as an industry standard retirement plan

b. CSR Disclosure

Manipulation of high CSR disclosure was adopted from Indofood Sukses Makmur LLC social responsibility report with modifications. The choice of this manipulation of high CSR disclosure is because Indofood Sukses Makmur LLC 
was ranked 10th in the SRI-KEHATI index per April 2015 period. Meanwhile, the manipulation of low CSR disclosure was adopted from Mayora Indah LLC social responsibility report with modification. The company was chosen because it was not listed in the 25 major SRI-KEHATI indices in the same period. SRI-KEHATI is an index released by the Indonesian Biodiversity Foundation (KEHATI) and IDX which contain 25 companies that are economically profitable and care about environmental sustainability.

The second instrument used is the Defining Issues Test (DIT) which measures the moral reasoning level individual. This instrument was developed by Rest (1979), using a case involving the ethical dilemma created by Kohlberg (McMahon, 2000). This instrument is used to assess individual moral stages at the level of Kohlberg's moral development. The index used to measure the results of the DIT survey is the P-score (principled moral reasoning score) which is often used as an indicator of moral judgment maturity. The P-score reflects the total score for the 5A, 5B, and 6 stages of moral development. A DIT set includes 6 cases, each of which is followed by 12 questions to answer the dilemma. The ethical dilemmas include: 1) Heinz and The Drug, 2) The Escaped Prisoner, 3) The Newspaper, 4) The Doctor's Dilemma, 5) Webster, and 6) Student Take-Over. Each question reflects different moral stages. Respondents will be asked to provide a rating for each question, and then sort the four most important questions. The ratings given are 1: very important, 2: important, 3: important enough, 4: less important, and 5: very unimportant.

This study uses a short version of DIT instrument containing 3 cases, among others: 1) Heinz and The Drug, 2) The Escaped Prisoner, and 3) The Newspaper. The three cases were selected as short version DIT components because they had the highest correlation compared to the other three cases, with P-score correlation of 0.93 with complete DIT P-score of samples of 160 subjects (Rest, 1986). Short version DIT is used because a complete set of DIT instruments contains too many case scenarios that can lead to information overload and fatigue for respondents (Weber, 1992). 


\subsection{Experimental Procedure}

Before the experiment began, the researcher read the introductory and experimental execution instructions to all participants. Then, researchers are handing out research contracts. In the research contract, information on the compensation that participants will receive for their participation in the experiment and the affirmation of the confidentiality of the information provided. Distribution of contracts and instruments are done using a randomized study. Therefore all participants have an equal chance to get into certain groups. After getting the contract, participants are given time to fill the contract first, and then it was collected to the researcher. Subsequently, participants were asked to fill in demographic data, do the evaluation instrument of the job seeker's attractiveness of the company, and ends with undertaking the instrument of moral reasoning. After completing all the tasks above, participants will receive the compensation promised in the contract.

\section{Results}

\subsection{Descriptive Statistics}

Total of experiment participants were 60 students, with proportional sex and composition. From those participants, 13 participants (21.67\%) did not pass the manipulation of the evaluation instrument of job seeker's attractiveness test, 9 participants $(15 \%)$ did not pass the DIT instrument, and the 1 participant data were excluded due to outlier (1.67\%). Thus, the numbers of a participant whose data can be further processed are 37 participants (61.67\%).

Table 1 shows the number of participants, mean (average), and standard deviation in each experimental group. From the table, it can be seen that the group receiving high compensation information has a higher average interest than the group receiving low compensation information (groups $\mathrm{A}$ and $\mathrm{B}$ with average amount $=1,662>$ group $\mathrm{C}$ and $\mathrm{D}$ with average number $=1.551$ ). Groups that received high CSR disclosure had higher average interest than those who received low CSR disclosure (groups A and C with average number $=1.692>$ groups $B$ and $D$ with average number $=1.521)$. Meanwhile as expected, the groups receiving low compensation information and high CSR 
disclosure had higher rates than those receiving high compensation information and low CSR disclosure (group $\mathrm{C}=0.824>$ group $\mathrm{B}=0.794$ ). Also, Table 1 also shows the diversity of individual moral reasoning levels held by participants in each experimental group.

Table 1.

Descriptive statistics

\begin{tabular}{|l|l|l|l|l|}
\hline Group & Variables & $\mathbf{N}$ & Mean & Standard Deviation \\
\hline A & Interest & 11 & 0.868 & 0.060 \\
\cline { 2 - 5 } & Moral Reasoning & 11 & 0.424 & 0.130 \\
\hline \multirow{2}{*}{ B } & Interest & 10 & 0.794 & 0.064 \\
\cline { 2 - 5 } & Moral Reasoning & 10 & 0.260 & 0.075 \\
\hline C & Interest & 11 & 0.824 & 0.109 \\
\cline { 2 - 5 } & Moral Reasoning & 11 & 0.385 & 0.111 \\
\hline \multirow{2}{*}{ D } & Interest & 5 & 0.727 & 0.120 \\
\cline { 2 - 5 } & Moral Reasoning & 5 & 0.253 & 0.119 \\
\hline
\end{tabular}

\subsection{Statistical Test}

Normality test and homogeneity test is done before the ANOVA test to test the hypotheses 1,2, and 3. Table 2 shows the Shapiro-Wilk normality test results which conclude that all treatments for each independent variable have a value of sig. $>0.05$ which means that data is normally distributed. Also, data normality can be seen using QQ Plot which shows a straight line. Whereas, the homogeneity of the data was tested using Levene's homogeneity test of variance. Table 3 shows the results of homogeneity 
test data which leads to a conclusion that all independent variable is homogeneous with a value of sig. $>0.05$.

Table 2.

Shapiro-Wilk’s Normality Test Result

\begin{tabular}{|l|l|l|l|}
\hline & N & Sig. & Information \\
\hline Low compensation information & 16 & 0.276 & Normal \\
\hline High compensation information & 21 & 0.479 & Normal \\
\hline Low CSR disclosure & 15 & 0.204 & Normal \\
\hline High CSR disclosure & 22 & 0.197 & Normal \\
\hline
\end{tabular}

Table 3.

Homogeneity Test Results

\begin{tabular}{|l|l|l|l|l|l|}
\hline Independent Variables & Levene's Statistic & df1 & df2 & Sig. & Information \\
\hline Compensation Information & 3,232 & 1 & 35 & 0.081 & Homogeneous \\
\hline CSR Disclosure & 0,000 & 1 & 35 & 0.996 & Homogeneous \\
\hline
\end{tabular}

Classical assumption test consisted of a normality test, multicollinearity test, and heteroscedasticity test is being done before performing Moderated Regression Analysis (MRA) to test hypothesis 4. Like the ANOVA test, the normality test was performed using Shapiro-Wilk. Table 4 shows the results of the normality test which can be concluded that the dependent variable (company attractiveness from job seekers perspectives) is normally distributed with the value of sig. 0.115 (greater than $=0.05$ ). Multicollinearity test is done by comparing VIF and Tolerance value. The results of this 
test are shown in Table 5 which leads to a conclusion that the data does not meet the multicollinearity test.

Nevertheless, regression analysis can still be done, because regression analysis contains moderating variables (Moderated Regression Analysis) generally experience multicollinearity problem (Liana, 2009). The heteroscedasticity test was performed using the Glejjser test. The test results shown in Table 6 conclude that the data does not contain heteroscedasticity (sig.> 0.05). Therefore, the regression analysis can be performed.

Table 4.

Normality Test Results

\begin{tabular}{|l|l|l|l|l|}
\hline \multirow{2}{*}{} & \multicolumn{2}{|l|}{ Shapiro-Wilk } & \multirow{2}{*}{ Information } \\
\cline { 2 - 4 } & Statistic & df & Sig. & \\
\hline Interest & 0.952 & 37 & 0.115 & Normal \\
\hline
\end{tabular}

Table 5.

Multicollinearity Test Results

\begin{tabular}{|l|l|l|l|}
\hline Variables & Tolerance & VIF & Information \\
\hline Moral Reasoning & 0.179 & 5,575 & Non-Multicollinearity \\
\hline CSR Disclosure & 0.088 & 11,358 & Multicollinearity \\
\hline Moral Reasoning * CSR Disclosure & 0.045 & 22,199 & Multicollinearity \\
\hline
\end{tabular}


Table 6.

Heteroscedasticity Test Results

\begin{tabular}{|l|l|l|}
\hline Variables & Sig. & Information \\
\hline Moral Reasoning & 0.059 & Homoscedasticity \\
\hline CSR Disclosure & 0.363 & Homoscedasticity \\
\hline Moral Reasoning * CSR Disclosure & 0.135 & Homoscedasticity \\
\hline
\end{tabular}

\subsection{Hypothesis Testing}

Hypotheses 1, 2, and 3 in this study were analyzed using ANOVA. Table 7 shows the results of the ANOVA test to determine the effect of compensation information and CSR disclosure on the attractiveness of job seekers in the company.

Table 7.

ANOVA Test Results

\begin{tabular}{|l|l|l|l|l|l|}
\hline Source & Type III Sum of Squares & Df & Mean Square & F & Sig. \\
\hline Corrected Model & $0.075^{\mathrm{a}}$ & 3 & 0.025 & 3,324 & 0.031 \\
Intercept & 21,427 & 1 & 21,427 & 2833,927 & 0,000 \\
Compensation & 0.026 & 1 & 0.026 & 3,431 & 0.073 \\
CSR & 0.061 & 1 & 0.061 & 8,056 & 0.008 \\
Compensation * CSR & 0.001 & 1 & 0.001 & 0.143 & 0.708
\end{tabular}




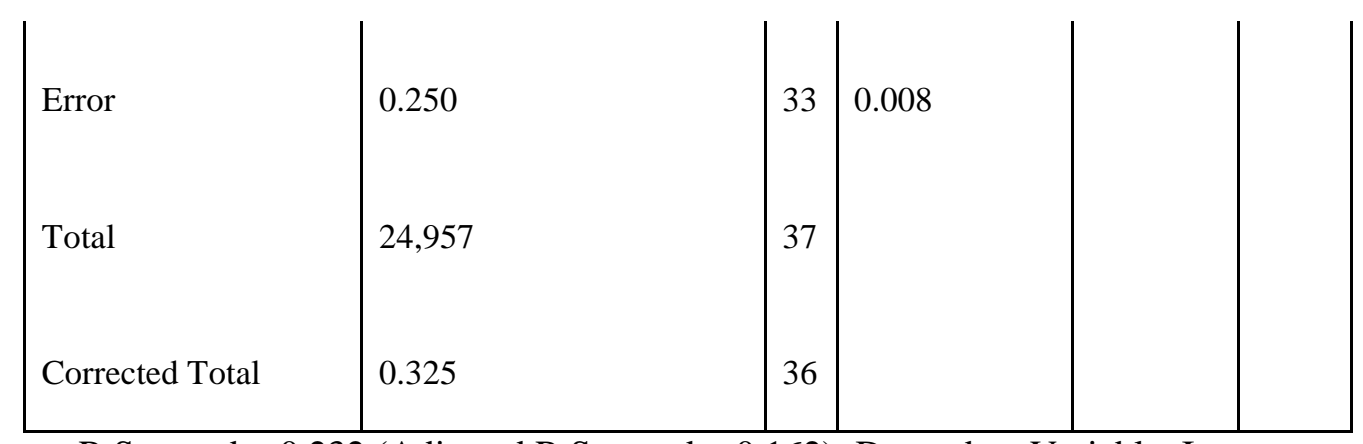

R Squared = 0,232 (Adjusted R Squared = 0,162); Dependent Variable: Interest

Hypothesis 1 predicts that job seekers are more interested in working in companies that offer higher compensation than the industry average than companies that offer compensation on the industry average. As indicated by Table 1, the average number of job seekers who get compensation information above the industry average (groups A and $\mathrm{B}$ ) is higher than the average of job seekers who receive compensation information by industry average (group C and D). However, the compensation information variable is not significant at the 0.05 level (value of $s i g=0.073$ ). This means that the compensation information has no significant effect on the attractiveness of the job seeker to the company. Therefore, hypothesis 1 is not supported by data. From this test, it can be concluded that although compensation information has no significant effect on the company attractiveness from job seekers point of view, in the case of ceteris paribus, job seekers will prefer to work in companies that offer higher compensation. These findings support the literature that employees are not only concerned with comprehensive compensation and benefits, but also non-monetary factors such as corporate values and culture (Arthur, 2001).

Hypothesis 2 predicts that job seekers are more interested in working in companies that have high CSR disclosure than companies with low CSR disclosure. Table 1 show groups that received high CSR disclosure (groups A and C) had higher rates than those who received low CSR disclosure (groups B and D). Table 7 confirms it statistically significant at the 0.05 level (value of sig. $=0.008$ ). Thus, it can be concluded that the disclosure of CSR significantly affects the attractiveness of job seekers in the company. 
Hence, hypothesis 2 is supported by data. These findings support the results of research conducted by Albinger and Freeman (2000) and Greening and Turban (2000) who found that the company's reputation for CSR activity significantly affected the company attractiveness from job seekers point of view.

Hypothesis 3 predicts that job seekers are more interested in working in companies with higher CSR disclosures with compensation around industry averages than in companies with low CSR disclosure rates with compensation above the industry average. Table 1 shows that groups received compensation information at industry averages and high CSR disclosure (group C) had a higher ratio than those who received compensation information above the industry average and low CSR disclosure (group B). However, the compensation information variable interacted with CSR disclosure variable is not significant at the 0.05 level (value of sig. $=0.708$ ). This means that information on CSR compensation and disclosure does not interact with each other in influencing the company attractiveness in the job seekers perspective. Job seekers will be more concerned with the reputation of the company formed by CSR disclosure than the compensation-related information offered by the company, and the two independent variables do not affect the dependent variable collectively. Thus, hypothesis 3 is not supported by data.

Hypothesis 4 was tested using the Moderated Regression Analysis (MRA). From Table 8 , it can be seen that the coefficient of moderating variables shown by the coefficient of Moral Reasoning * CSR disclosure has a value of -0.196 . This means that the moderating variable of moral reasoning weakens the influence of CSR disclosure on the company attractiveness to the job seekers. However, since the variable is not significant at the 0.05 level with the value of sig. $=0,502$, it can be concluded that the variable of moral reasoning does not moderate the influence of CSR disclosure on the interest of job seekers at the company. Therefore hypothesis 4 is not supported by the data. 
Table 8 .

MRA Test Results

\begin{tabular}{|l|l|l|l|}
\hline Model & Coefficient & $\mathbf{t}$ & Sig. \\
\hline Constants & 0.640 & 9,534 & 0,000 \\
\hline Moral Reasoning & 0.511 & 2.066 & 0.047 \\
\hline CSR Disclosure & 0.079 & 0.858 & 0.397 \\
\hline $\begin{array}{l}\text { Moral Reasoning } \\
\text { CSR Disclosure }\end{array}$ & -0.196 & $-0,679$ & 0.502 \\
\hline
\end{tabular}

The insignificant effect of moral reasoning in moderating CSR disclosure to the attractiveness of jobseekers in the firm is due to the DIT instrument used to determine the level of individual moral reasoning in this study measuring the $P$-score reflecting the total value for the stage of moral development in the post-conventional stage. At this stage, a person no longer makes a moral judgment based on self-interest (egocentric) or to meet the expectations of the surrounding environment, but based on the moral principles he believes in a broader perspective. Hence, one's thinking patterns are at the post-conventional level related to ethical dilemmas is vast. This allows for a variety of other factors that influence the perspective in looking at social phenomena. Thus, the high level of one's moral reasoning does not necessarily increase the influence of corporate CSR disclosure of one's interest in the company.

The negatives of the moderating coefficients contradict the opinions of Coldwell et al. (2008) which states that a person who has a high level of moral reasoning will not likely be interested in working for a company that does not have good social responsibility. According to Coldwell, et al. (2008), someone who has moral reasoning at the post-conventional level has a higher ethical expectation than those at conventional and pre-conventional levels. Thus, a higher level of individual moral reasoning means the higher one's expectations of ethical practice in the company. Contrary to Coldwell's 
opinion, et al. (2008), Turner and Barling (2002) suggest that high levels of individual moral reasoning are related to the nature of transformational leadership. A person with a transformational leadership trait who has a high level of moral reasoning tends to attempt influencing and motivating his or her surroundings to act on what he believes to be morally right. Thus, the negative coefficients of the moderating variable are likely due to the leadership characteristics of the respondents which are transformational. Therefore, the higher level of individual moral reasoning stirs them to try to influence the company with low CSR disclosure to improve and enhance corporate social responsibility activities and disclose it to the public.

\section{Conclusions, Implications, and Limitations of Research}

The results of hypothesis testing show that job seekers consider more on noneconomic factors rather than economic factors in determining the company as their place to work in the future. The non- economic factor is represented by the CSR disclosure of companies, while economic factors are represented by information related to the compensation offered by the company. These findings can provide recommendations to various companies in Indonesia to carry out social responsibility activities well and express them extensively to the public. In this way, companies can reduce the uncertainty of information held by external stakeholders' company, one of which is the prospective employee. The recruitment process is one of the crucial stages in the Human Resource Management process that has a major contribution to the company's ability to achieve its objectives. Hence, the series of stages in recruitment becomes an important concern. To improve the company's ability to attract qualified job seekers, extensive CSR disclosure is required. Meanwhile, the study also recommends companies not to make compensation packages the only factor that might increase their appeal in the eyes of fresh graduates' job seekers, since compensation-related information proved to be insignificant in influencing the attractiveness of the particular job seekers towards the company.

Meanwhile, the role of individual moral reasoning in moderating the influence of CSR disclosure on the company attractiveness from job seekers point of view has not 
been proven empirically. This is due to the presence of other factors that may affect the unexamined in this study. One example of such factors is the leading nature of the experimental participants. Also, the proof of this hypothesis can contribute theoretically. Evidence of hypothesis 4 can contribute to science. This is because as far as the researcher's knowledge, no previous research has tried to prove empirically how the role of moral reasoning in moderating the influence of CSR disclosure on the company attractiveness from job seekers perspective.

There are some limitations in this study related to study samples and variables examined. However, these limitations may not affect the validity if this study. This study is limited to testing only moral reasoning variables. Other variables that may be relevant or potentially such as the individual characteristics of the job seeker are not researched. Through, the uniqueness of individual characteristics can be one of the good moderating variables. For that, in subsequent research, the characteristics of individuals should be observed and examined.

\section{References}

Albinger, H. S., \& Freeman, S. J. (2000). Corporate Social Performance and Attractiveness as an Employer to Different Job Seeking Populations. Journal of Business Ethics, 28, 243-253.

Arthur, D. (2001). The Employee Recruitment and Retention Handbook. New York, NY: AMACOM.

Belt, J. A., \& Paolillo, J. G. (1982). The Influence of Corporate Image and Specificity of Candidate Qualifications on Response to Recruitment Advertisement. Journal of Management 8, 8(1), 105-112.

Bursa Efek Indonesia. (2015). Pengumuman Saham yang Masuk dan Keluar dalam Perhitungan Indeks SRI-KEHATI. Bursa Efek Indonesia.

Clarkson, P. M., Li, Y., Richardson, G. D., \& Vasvari, F. P. (2008). Revisiting the relation between environmental performance and environmental disclosure: An empirical analysis. Accounting, Organizations and Society, 33(4-5), 303-327.

Coldwell, D. A., Billsberry, J., Meurs, N. v., \& Marsh, P. J. (2008). The Effects of Person-Organization Ethical Fit on Employee Attraction and Retention: 
Towards a Testable Explanatory Model. Journal of Business Ethics, 78, 611622.

Dolan, K. A. (1997, June 2). Kinder, Gentler M.B.A.s. 39-40. Forbes.

Fombrun, C., \& Shanley, M. (1990). What's in a Name? Reputation Building and Corporate Strategy. Academy of Management Journal, 33(2), 233-258.

Gatewood, R. D., Gowan, M. A., \& Lautenschlager, G. J. (1993). "Corporate Image, Recruitment Image, And Initial Job Choice Decisions. Academy of Management Journal, 36(2), 414-427.

Greening, D. W., \& Turban, D. B. (2000). Corporate Social Performance as a Competitive Advantage in Attracting a Quality Workforce. Business Society, 39(3), 254-280.

Kementerian Perindustrian Republik Indonesia. (2012). Kualitas Tenaga Kerja RI Rendah. Dipetik October 23, 2016, from http://www.kemenperin.go.id/artikel/8161/Kualitas-Tenaga-Kerja-RI-Rendah

Kohlberg, L. (1981). The Philosophy of Moral Development: Moral Stages and the Idea of Justice. San Francisco: Harper \& Row.

Liana, L. (2009). Penggunaan MRA dengan Spss untuk Menguji Pengaruh Variabel Moderating terhadap Hubungan antara Variabel Independen dan Variabel Dependen. Jurnal Teknologi Informasi DINAMIK, XIV(2), 90-97.

McMahon, J. (2000, April 28). The Effects of Cognitive Moral Development and Reinforcement Contingencies on Ethical Decision Making. Master Thesis. Blacksburg, VA: Faculty of the Virginia Polytechnic Institute and State University.

Pfeffer, J. (1994). Competitive advantage through people. California Management Review, 36(2), 9-28.

Piaget, J. (1932). The Moral Judgement of the Child. London: Kegan Paul.

Rest, J. R. (1979). Development in Judging Moral Issues. Minneapolis, MN: University of Minnesota Press.

Rest, J. R. (1986). DIT Manual 3rd Edition. Minneapolis, MN: University of Minnesota Centre for the Study of Ethical Development.

Rockness, H. O., Bazley, J. D., \& Nikolai, L. A. (1977). Variance analysis for pollution control. Management Accounting, 51-54. 
Snell, S. A., Youndt, M. A., \& Wright, P. M. (1996). Establishing a framework for research in strategic human resource management: Merging resource theory and organizational learning. Research and Human Resources Management, 14, 6190 .

Tajfel, H., \& Turner, J. (1979). An Integrative Theory of Intergroup Conflict. Dalam W. Austin, \& S. Worchel, The Social Psychology of Intergroup Relations (hal. 3347). Brooks-Cole.

Taylor, M. S., \& Collins, C. J. (2000). Organizational recruitment: Enhancing the intersection of research and practice. Oxford, UK: Blackwell Publishing.

Turner, N., \& Barling, J. (2002). Transformational Leadership and Moral Reasoning. Journal of Applied Psychology, 87(2), 304-311.

Undang-undang Republik Indonesia Nomor 40 Tahun 2007 tentang Perseroan Terbatas. (2007).

Velasquez, M. G. (2012). Business Ethics: Concept and Cases. Upper Saddle River, NJ: Pearson Education, Inc.

Weber, J. (1992). Scenarios in Business Ethics Research: Review, Critical Assessment, and Recommendations. Business Ethics Quarterly, 2, 137-160.

Wolk, H. I., Dodd, J. L., \& Rozycki, d. J. (2013). Accounting Theory: Conceptual Issues in Political and Economic Environment. Thousand Oaks, California: SAGE. 